\title{
A Study on Floral Morphology of Brinjal Genotypes in Gangetic-Alluvial Zone of West Bengal, India
}

\author{
Arindam Das ${ }^{1,2^{*}}$, Manas Kumar Pandit ${ }^{2}$, Sanjay Bairagi ${ }^{2}$, \\ Shubhrajyoti Saha ${ }^{2}$ and Kola Muthaiah ${ }^{1}$
}

\author{
${ }^{1}$ Division of Vegetable Crops, ICAR-Indian Institute of Horticultural Research, \\ Bengaluru- 560 089, Karnataka, India \\ ${ }^{2}$ Department of Vegetable Crops, Bidhan Chandra Krishi Viswavidyalaya, \\ Mohanpur-741252, West Bengal, India \\ *Corresponding author
}

\begin{tabular}{|c|c|}
\hline & A B S T R A C T \\
\hline & \multirow{7}{*}{$\begin{array}{l}\text { The present experiment was conducted during autumn-winter seasons } 2014-2015 \text { and } \\
2015-2016 \text { at Bidhan Chandra Krishi Viswavidyalaya, West Bengal to study the floral } \\
\text { morphology, anthesis-full bloom-anther dehiscense-stigma receptivity, parthenocarpy and } \\
\text { other floral characters of eggplant. Twenty one brinjal genotypes were used for this } \\
\text { experiment with a randomized block design with three replications. The least time required } \\
\text { for flower bud initiation was in the genotype BCB-16 (40.83 DAT) and highest in BCB-1 } \\
\text { ( } 58.17 \text { DAT). The maximum days required for } 50 \% \text { plants to be flowered has been } \\
\text { reported in BCB-13 (68.33 DAT) and minimum in BCB-22 ( } 50.50 \text { DAT). The highest } \\
\text { ratio of (LS+MS): (PS+SS) flowers has been recorded in the genotype BCB-10 (11.52) } \\
\text { followed by BCB-8(10.33) and lowest in BCB-11(0.56). Ovary diameter and weight were } \\
\text { much higher in the long styled flowers than the rest. Anthesis starts earliest in BCB-18 } \\
\text { (6:14 a.m.) and latest by 7:51 a.m. in BCB- } 11 \text {. Full bloom stage generally occurred from } \\
6: 50 \text { a.m. (BCB-17) to 8:52 a.m. (BCB-15) and anther dehiscence ranged from 7:00 a.m. } \\
\text { (BCB-17) to 9:20 a.m. (BCB-15). Parthenocarpic fruit set was noted only in BCB-6, BCB- } \\
11 \text { BCB-14, BCB-15 and BCB-16. The propensity to parthenocarpic fruit set is low in } \\
\text { brinjal. }\end{array}$} \\
\hline Keywords & \\
\hline & \\
\hline $\begin{array}{l}\text { Anthesis, Stigma } \\
\text { receptivity, } \\
\text { Parthenocarpy. }\end{array}$ & \\
\hline Article Info & \\
\hline $\begin{array}{l}\text { Accepted: } \\
\text { 26 September } 2017 \\
\text { Available Online: } \\
10 \text { October } 2017\end{array}$ & \\
\hline & \\
\hline
\end{tabular}

\section{Introduction}

Brinjal, eggplant or aubergine (Solanum melongena L.) is the most popular and widely cultivated warm season vegetable crop in the central, southern and south-east Asia. Study of floral biology has great importance in plant breeding and hybrid seed production. Flowering in brinjal is extra-axilliary and the pattern of flowering is commonly of three types namely, solitary, cluster (cyme) and mixed and it is the most crucial factor determining the yield of cultivated eggplants. Genotype, as well as environmental factors also influences eggplant flowering and the flower morphology, especially the style length which determines fruit set. According to Passam and Bolmatis (1997), the style length in eggplant is a varietal characteristic. Eggplant has 4 types of flowers viz. 1) long styled with large ovary, 2) medium styled with medium sized ovary, 3) pseudo short- 
styled with rudimentary ovary, and 4) trueshort-styled with very rudimentary ovary. Heterostyly in brinjal determines and facilitates self or cross-pollination and subsequent fruit set. It played an important role in augmenting genetic diversity in melongena cultivars through partial crosspollination occurring in nature, though it is basically an autogamous crop. Long styled flowers (the stigma is above the stamen) or medium styled flowers (stigma is on the same level as the stamen) are always more appreciable in the number than pseudo and short-styled flowers (the stigma is below the stamen). Pseudo and short-styled flowers fail to set fruits, whereas long and medium-styled flowers produce fruits, but short-styled flowers are not totally sterile (Chen, 2001). Nothmannet et al., (1983) stated that stylar heteromorphism affected fruit set more than did the position of the flower in the cluster. Passam and Bolmatis (1997) stressed that the proximity of the stigma to the anther pores at anthesis influences fruit set, fruit size and seed content, but not seed quality. Fruit weight and seed formation were maximal in flowers with the stigmata at maturity situated close to the anther pores.

\section{Materials and Methods}

The present experiment was conducted during autumn-winter seasons 2014-2015 and 20152016 at the AB Seed Farm of Bidhan Chandra Krishi Viswavidyalaya, Kalyani, West Bengal. Average temperature and relative humidity of first year were $25.3^{\circ} \mathrm{C}$ and $72.94 \%$ and in second year it was $25.7^{\circ} \mathrm{C}$ and $76.44 \%$. Twenty one brinjal genotypes were used for this experiment (Table-1). Present investigation was carried out in a randomized block design with three replications. Randomly five plants from each genotype were taken for recording observations in each replication. Mean data pooled over the years has been furnished and statistically analyzed for all the characters. Mean sum of square is calculated for both the years and the higher value has been divided by the lower one. If this value ( $\mathrm{F} \mathrm{cal}$ ) remains lower than the $\mathrm{F}$ tab value, it indicates sufficient homogeinity between two seasons and the pool data have been furnished. Five buds per genotype in each replication were tagged to record observations. Anther dehiscence was recorded by visual observation of presence of pollens on the apical pore of the anther by means of a magnifying glass. Two seasons' average data have been furnished. After hand pollination stigma receptivity was studied by fruit set method with viable fresh pollen in two ways viz.1. Three hour interval on the day of anthesis. 2. Daily interval from 6 days before anthesis to 2 days after anthesis and this phenomenon was conducted for 3 genotypes namely BCB-3 (oval type), BCB-9 (round type) and BCB- 11 (long type). Twenty flowers per genotype for each stage has been hand pollinated (emusculation-pollinationbagging) and resulted fruit setting was counted for calculation of stigma receptivity. Parthenocarpy was tested by two ways viz. a) clipping off the stigmatic head in the early morning of the day of anthesis and b) emasculation of anthers day before anthesis. Five flowers per replication of every genotype for each of the two ways were studied for parthenocarpic fruit set.

\section{Results and Discussion}

\section{Flower bud initiation (Days after Transplanting)}

Though flower initiation of brinjal is a varietal character, it also influenced predominantly by temperature and high humidity. Quagliotti (1979) opined that it generally takes about 55-110 DAS to first flowering in eggplant. But in this experiment, the least time required for flower bud initiation was reported in BCB-16 (40.83 
DAT) followed by BCB-27 (41.17 DAT) and BCB-22 (41.83 DAT) and they were, however, statistically at par (Table-2). The maximum days required for flower bud initiation has been noticed in case of BCB-1 (58.17 DAT) followed by BCB-14 (56.00 DAT), BCB-15 (55.17 DAT) and BCB-9 (54.00 DAT). Similar work has been done by Gavade and Ghadge (2015), but Dhaka and Soni (2012) reported 69.60 days for first flowering.

\section{0\% Flowering (Days after transplanting)}

The minimum time required for $50 \%$ plants to flower (Table-2), was in BCB-22 (50.50 DAT) followed by BCB-12 (51.17 DAT), BCB-10 (51.33 DAT), BCB-21 (51.50 DAT) and BCB-3 (51.83 DAT) and they were, however, statistically at par. The maximum days required for this has been reported in BCB-13 (68.33 DAT) followed by BCB-9 (66.50 DAT), BCB-11 (65.33 DAT), BCB-1 (65.13 DAT) and BCB-18 (64.00 DAT) and there was no significance difference among them. The present findings are in consonance with the results obtained by Vandana et al., (2014), Vidhya and Kumar (2015).

\section{Total flowering period (days)}

Table-2 clearly showed that BCB-8 has the highest total flowering periods (133.10 days) followed by BCB-12 (113.69 days) and BCB27 (109.72 days). The genotype BCB-16 was reported as lowest total flowering period (86.67 days) followed by BCB-2 (92.42 days), BCB-4 (94.20 days), BCB-15 (96.17) and BCB-14 (99.00 days).

\section{Ratio of productive and non-productive flowers}

The highest ratio of (LS+MS): (PS+SS) flowers (Table-2) has been recorded in the genotype BCB-10 (11.52) followed by BCB-
8(10.33) and lowest in BCB-11(0.56) followed by BCB-18(0.85). In 2010, Pandit et $a l$., reported that the higher the ratio of longstyle and medium-style flowers to nonproductive flowers (i.e. pseudo-short and true short style flowers), better will be the fruit set in brinjal.

\section{Anther, Style and ovary character}

A comparison of anther and style length along with ovary characters have been furnished in Tables-3 and 4. Anther lengths correspond with that of style lengths in all the four types of brinjal flowers. Quite obviously ovary diameter and weight were much higher in the long styled flowers than the rest. Heterostyly in brinjal determines and facilitates self or cross-pollination and subsequent fruit set.

Long and peristyly conditions set fruits. In other words, style lengths longer than the anther tips or at around the peripherals of the anther sacs can set fruits. The unfruitfulness of the short styled flowers under natural conditions may be due to their very low ovary diameter and ovary weight. In the present investigation, ovary diameter of the long styled flowers were noted to be almost three times highly than the short styled flowers, on an average. The actual reasons for heterostyly and development of ovary up to rudimentary scale are yet to be explained. Passam and Bolmatis (1997) achieved the highest percentage of fruit set from flowers with long style and medium style pistils.

Domestication, mutation, natural outcrossing, natural selection and human selection, particularly hybridization all have created immense genetic diversity in the cultivated brinjal. Heterostyly played an important role in augmenting genetic diversity in melongena cultivars through partial crosspollination occurring in nature, though it is basically an autogamous crop. 
Table.1 Name and source of the genotypes

\begin{tabular}{|c|c|c|}
\hline Symbol & Name & Source \\
\hline BCB- 1 & Sada local & Banamalipara, Nadia, West Bengal \\
\hline BCB- 2 & Makra & Kanthaltala, Nadia, West Bengal \\
\hline BCB- 3 & Makra mid-long & Madanpur, Nadia, West Bengal \\
\hline BCB- 4 & Daab begun & Kalyani, Nadia, West Bengal \\
\hline BCB- 5 & Thubi & Kalyani, Nadia, West Bengal \\
\hline BCB- 6 & Bhangar & Ghoragacha, Nadia, West Bengal \\
\hline BCB- 7 & Gola & Chakdaha, Nadia, West Bengal \\
\hline BCB- 8 & Hajari & Tekkali, Andhra Pradesh \\
\hline BCB- 9 & Debgiri & Barasat, North 24 Parganas, West Bengal \\
\hline BCB- 10 & Simanta & Bhootta bazaar, Kalyani, Nadia, West Bengal \\
\hline BCB- 11 & Sada lamba & Bangaon, N-24 Pgs, West Bengal \\
\hline BCB- 12 & Kranti & New Delhi \\
\hline BCB- 13 & Anubhav & New Delhi \\
\hline BCB- 14 & Tara & New Delhi \\
\hline BCB- 15 & Purushottom & Raipur, Chattishgarh \\
\hline BCB- 16 & Purple round & New Delhi \\
\hline BCB- 17 & Kooli & Balagarh, Hooghly, West Bengal \\
\hline BCB- 18 & Utkal & Bhubeneswar, Odissa \\
\hline BCB- 21 & Jhuri & Basantapur, Nadia, West Bengal \\
\hline BCB- 22 & Makra mid & Haringhata, Nadia, West Bengal \\
\hline BCB- 27 & Kalyani & Kalyani market, West Bengal \\
\hline
\end{tabular}

Table.2 Flower bud emergence, flowering span and ratio of productive and Non-productive flowers

\begin{tabular}{|c|c|c|c|c|}
\hline Genotype & $\begin{array}{c}\text { Floral bud } \\
\text { emergence (DAT) }\end{array}$ & $\begin{array}{c}\text { Days to 50\% } \\
\text { flowering (DAT) }\end{array}$ & $\begin{array}{c}\text { Total flowering period } \\
\text { (Days) }\end{array}$ & $\begin{array}{c}\text { (LS+MS) : } \\
\text { (PS+SS) }\end{array}$ \\
\hline BCB-1 & 58.17 & 65.13 & 105.12 & 1.92 \\
\hline BCB-2 & 49.50 & 61.08 & 92.42 & 7.40 \\
\hline BCB-3 & 42.00 & 51.83 & 117.97 & 5.89 \\
\hline BCB-4 & 42.33 & 54.00 & 94.20 & 6.87 \\
\hline BCB-5 & 43.33 & 62.00 & 119.63 & 1.92 \\
\hline BCB-6 & 50.33 & 58.17 & 112.93 & 7.28 \\
\hline BCB-7 & 46.67 & 57.17 & 105.13 & 7.83 \\
\hline BCB-8 & 49.00 & 54.00 & 133.10 & 10.33 \\
\hline BCB-9 & 54.00 & 66.50 & 102.38 & 8.72 \\
\hline BCB-10 & 42.83 & 51.33 & 100.10 & 11.52 \\
\hline BCB-11 & 45.67 & 65.33 & 110.77 & 0.56 \\
\hline BCB-12 & 42.67 & 51.17 & 126.63 & 3.48 \\
\hline BCB-13 & 51.83 & 68.33 & 100.42 & 7.05 \\
\hline BCB-14 & 56.00 & 60.50 & 99.00 & 1.32 \\
\hline BCB-15 & 55.17 & 59.67 & 96.17 & 3.21 \\
\hline BCB-16 & 40.83 & 55.50 & 86.67 & 1.35 \\
\hline BCB-17 & 43.00 & 58.50 & 106.27 & 4.48 \\
\hline BCB-18 & 50.00 & 64.00 & 100.83 & 0.85 \\
\hline BCB-21 & 45.33 & 51.50 & 123.62 & 2.47 \\
\hline BCB-22 & 41.83 & 50.50 & 118.00 & 3.18 \\
\hline BCB-27 & 41.17 & 57.33 & 120.83 & 2.96 \\
\hline SEm $( \pm)$ & 1.41 & 1.24 & 2.44 & 0.92 \\
\hline CD $(0.05)$ & 3.95 & 3.48 & 6.83 & 2.62 \\
\hline
\end{tabular}


Table.3 Anther and style length

\begin{tabular}{|c|c|c|c|c|c|c|c|c|}
\hline \multirow{2}{*}{ Genotype } & \multicolumn{3}{|c|}{ Anther length (mm) } & \multicolumn{5}{c|}{ Style length (mm) } \\
\cline { 2 - 10 } & LS & MS & PS & SS & LS & MS & PS & SS \\
\hline BCB-1 & 12.48 & - & - & 8.99 & 11.39 & - & - & 0.74 \\
\hline BCB-2 & 12.96 & - & - & 11.59 & 9.84 & - & - & 1.51 \\
\hline BCB-3 & 11.59 & 12.77 & 10.48 & 9.17 & 9.34 & 8.7 & 2.73 & 1.7 \\
\hline BCB-4 & - & 12.54 & - & 4 & - & 10.09 & - & 2.28 \\
\hline BCB-5 & 10.93 & - & - & 10.35 & 10.12 & - & - & 1.42 \\
\hline BCB-6 & 11.82 & - & - & - & 11.42 & - & - & - \\
\hline BCB-7 & 13.73 & 13.34 & - & 12.96 & 10.87 & 10 & - & 2.14 \\
\hline BCB-8 & 11.48 & 11.88 & - & - & 11.01 & 10.87 & - & - \\
\hline BCB-9 & 12.35 & - & - & - & 11.27 & - & - & - \\
\hline BCB-10 & 13.57 & - & 13.24 & - & 9.77 & - & 7.53 & - \\
\hline BCB-11 & 13.62 & - & - & 11.08 & 10.41 & - & - & 2.39 \\
\hline BCB-12 & 10.98 & 12.82 & - & 9.96 & 10.79 & 9.55 & - & 1.65 \\
\hline BCB-13 & 12.32 & 10.65 & - & - & 9.08 & 8.92 & - & - \\
\hline BCB-14 & 10.61 & - & - & 10.57 & 13.23 & - & - & 2.2 \\
\hline BCB-15 & - & 12.02 & - & - & - & 11 & - & - \\
\hline BCB-16 & 9.82 & - & 9.25 & 8.38 & 7.94 & - & 3.44 & 1.52 \\
\hline BCB-17 & 12.73 & - & - & 10.16 & 12.33 & - & - & 3.6 \\
\hline BCB-18 & 12.31 & - & - & - & 13.53 & - & - & - \\
\hline BCB-21 & 8.82 & - & 9.3 & - & 9.65 & - & 2.86 & - \\
\hline BCB-22 & 9.79 & - & - & - & 9.96 & - & - & - \\
\hline BCB-27 & 9.74 & - & 9.84 & - & 8.76 & - & 3.69 & - \\
\hline
\end{tabular}

Table.4 Ovary characters

\begin{tabular}{|c|c|c|c|c|c|c|c|c|}
\hline \multirow{2}{*}{ Genotype } & \multicolumn{3}{|c|}{ Ovary Diameter(mm) } & \multicolumn{5}{c|}{ Ovary Weight(g) } \\
\cline { 2 - 9 } & LS & MS & PS & SS & LS & MS & PS & SS \\
\hline BCB-1 & 5.41 & - & - & 1.95 & 0.0912 & - & - & 0.00695 \\
\hline BCB-2 & 6.93 & - & - & 2.16 & 0.195 & - & - & 0.006 \\
\hline BCB-3 & 5.12 & 4.77 & 4.42 & 1.42 & 0.1 & 0.09 & 0.06 & 0.01 \\
\hline BCB-4 & - & 6.15 & - & 4.05 & - & 0.157 & - & 0.0099 \\
\hline BCB-5 & 4.48 & - & - & 1.36 & 0.0507 & - & - & 0.0016 \\
\hline BCB-6 & 6.5 & - & - & - & 0.1173 & - & - & - \\
\hline BCB-7 & 5.72 & 5.03 & - & 3.74 & 0.1774 & 0.1053 & - & 0.0239 \\
\hline BCB-8 & 3.14 & 4.14 & - & - & 0.09 & 0.04 & - & - \\
\hline BCB-9 & 6.07 & - & - & - & 0.1281 & - & - & - \\
\hline BCB-10 & 6.8 & - & 5.23 & - & 0.1989 & - & 0.077 & - \\
\hline BCB-11 & 4.7 & - & - & 1.95 & 0.11 & - & - & 0.01 \\
\hline BCB-12 & 3.6 & 3.25 & - & 1.3 & 0.0313 & 0.039 & - & 0.0007 \\
\hline BCB-13 & 4.73 & 4.74 & - & - & 0.10385 & 0.06 & - & - \\
\hline BCB-14 & 2.46 & - & - & 1.98 & 0.02 & - & - & 0.0026 \\
\hline BCB-15 & - & 4.03 & - & - & - & 0.0698 & - & - \\
\hline BCB-16 & 6.73 & - & 5.37 & 3.81 & 0.23 & - & 0.18 & 0.03 \\
\hline BCB-17 & 2.31 & - & - & 1.56 & 0.0168 & - & - & 0.0048 \\
\hline BCB-18 & 3.24 & - & - & - & 0.0332 & - & - & - \\
\hline BCB-21 & 2.78 & - & 2.97 & - & 0.03 & - & 0.03 & - \\
\hline BCB-22 & 2.98 & - & - & - & 0.03 & - & - & - \\
\hline BCB-27 & 4.86 & - & 4.27 & - & 0.12 & - & 0.1 & - \\
\hline
\end{tabular}


Table.5 Other floral characters

\begin{tabular}{|c|c|c|c|c|c|c|c|}
\hline Genotype & $\begin{array}{c}\text { Flowering } \\
\text { pattern }\end{array}$ & \begin{tabular}{|c|}
$\begin{array}{c}\text { No. of flowers/ } \\
\text { cyme }\end{array}$ \\
\end{tabular} & $\begin{array}{c}\text { Ratio of } \\
\text { (ls:ms:ps:ss) }\end{array}$ & $\begin{array}{l}\text { Corolla } \\
\text { colour }\end{array}$ & $\begin{array}{c}\text { Calyx } \\
\text { colour }\end{array}$ & $\begin{array}{c}\text { Calyx } \\
\text { spinyness } \\
\end{array}$ & $\begin{array}{c}\text { Flower } \\
\text { structure }\end{array}$ \\
\hline BCB-1 & $\begin{array}{c}\text { Solitary + } \\
\text { Cluster }\end{array}$ & 2 to 3 & $1: 1: 0: 4$ & White & Green & Smooth & $\begin{array}{c}\text { Fully } \\
\text { opened }\end{array}$ \\
\hline BCB-2 & Solitary & 1 & $4: 1: 1: 1$ & Pale violet & Green & $\begin{array}{l}\text { Highly } \\
\text { thorny }\end{array}$ & $\begin{array}{l}\text { Fully } \\
\text { opened }\end{array}$ \\
\hline BCB-3 & $\begin{array}{c}\text { Solitary + } \\
\text { Cluster }\end{array}$ & 3 to 5 & $1: 3: 1: 2$ & Light violet & Green & $\begin{array}{l}\text { Medium } \\
\text { thorny }\end{array}$ & $\begin{array}{c}\text { Fully } \\
\text { opened }\end{array}$ \\
\hline BCB-4 & Solitary & 1 & $0: 5: 0: 1$ & Light violet & Green & Smooth & $\begin{array}{c}\text { Fully } \\
\text { opened }\end{array}$ \\
\hline BCB-5 & $\begin{array}{c}\text { Solitary + } \\
\text { Cluster }\end{array}$ & 2 to 6 & $2: 0: 0: 4$ & $\begin{array}{c}\text { Bluish } \\
\text { violet }\end{array}$ & $\begin{array}{c}\text { Dark } \\
\text { purple }\end{array}$ & Smooth & $\begin{array}{c}\text { Fully } \\
\text { opened }\end{array}$ \\
\hline BCB-6 & Solitary & 1 & 4:0:0:0 & Light & Green & Smooth & $\begin{array}{c}\text { Semi } \\
\text { opened }\end{array}$ \\
\hline BCB-7 & $\begin{array}{c}\text { Solitary + } \\
\text { Cluster }\end{array}$ & 2 to 3 & 1:1:0:6 & Light violet & Green & Smooth & $\begin{array}{c}\text { Fully } \\
\text { opened }\end{array}$ \\
\hline BCB-8 & $\begin{array}{c}\text { Solitary + } \\
\text { Cluster }\end{array}$ & 4 to 6 & 4.5:1:0:0 & Light violet & $\begin{array}{l}\text { Light } \\
\text { purple }\end{array}$ & Smooth & $\begin{array}{c}\text { Fully } \\
\text { opened }\end{array}$ \\
\hline BCB-9 & Solitary & 1 & 4:0:0:0 & Light violet & Green & $\begin{array}{l}\text { Medium } \\
\text { thorny }\end{array}$ & $\begin{array}{c}\text { Fully } \\
\text { opened }\end{array}$ \\
\hline BCB-10 & $\begin{array}{c}\text { Solitary + } \\
\text { Cluster }\end{array}$ & 1 to 3 & $1: 0: 2: 0$ & Light violet & Green & Smooth & $\begin{array}{l}\text { Fully } \\
\text { opened }\end{array}$ \\
\hline BCB-11 & $\begin{array}{c}\text { Solitary + } \\
\text { Cluster }\end{array}$ & 2 to 4 & $2: 0: 0: 3$ & Light violet & Green & Smooth & $\begin{array}{c}\text { Fully } \\
\text { opened }\end{array}$ \\
\hline BCB-12 & $\begin{array}{c}\text { Solitary + } \\
\text { Cluster }\end{array}$ & 3 to 4 & $1: 1: 0: 3.2$ & Light violet & Green & $\begin{array}{l}\text { Highly } \\
\text { thorny }\end{array}$ & $\begin{array}{c}\text { Fully } \\
\text { opened }\end{array}$ \\
\hline BCB-13 & Solitary & 1 & $2: 2: 0: 0$ & Light violet & Green & Smooth & $\begin{array}{c}\text { Fully } \\
\text { opened }\end{array}$ \\
\hline BCB-14 & $\begin{array}{c}\text { Solitary + } \\
\text { Cluster }\end{array}$ & 3 to 4 & $1: 0: 0: 4.5$ & Light violet & $\begin{array}{l}\text { Light } \\
\text { purple }\end{array}$ & Smooth & $\begin{array}{c}\text { Fully } \\
\text { opened }\end{array}$ \\
\hline BCB-15 & Solitary & 1 & $0: 5: 0: 0$ & $\begin{array}{l}\text { Greenish } \\
\text { white }\end{array}$ & Green & Smooth & $\begin{array}{c}\text { Fully } \\
\text { opened }\end{array}$ \\
\hline BCB-16 & $\begin{array}{c}\text { Solitary + } \\
\text { Cluster }\end{array}$ & 2 to 5 & $1: 0: 1: 2.1$ & Light violet & Green & Smooth & $\begin{array}{c}\text { Fully } \\
\text { opened }\end{array}$ \\
\hline BCB-17 & $\begin{array}{c}\text { Solitary + } \\
\text { Cluster }\end{array}$ & 2 to 3 & 5:0:0:10 & $\begin{array}{l}\text { Bluish } \\
\text { violet }\end{array}$ & $\begin{array}{c}\text { Dark } \\
\text { purple }\end{array}$ & Smooth & $\begin{array}{c}\text { Half } \\
\text { opened }\end{array}$ \\
\hline BCB-18 & $\begin{array}{c}\text { Solitary + } \\
\text { Cluster }\end{array}$ & 3 to 5 & $6: 0: 0: 15$ & Light violet & Green & Smooth & $\begin{array}{c}\text { Fully } \\
\text { opened }\end{array}$ \\
\hline BCB-21 & $\begin{array}{c}\text { Solitary + } \\
\text { Cluster }\end{array}$ & 3 to 6 & $1: 0: 0: 2$ & Light violet & $\begin{array}{l}\text { Light } \\
\text { purple }\end{array}$ & $\begin{array}{l}\text { Highly } \\
\text { thorny }\end{array}$ & $\begin{array}{c}\text { Half } \\
\text { opened }\end{array}$ \\
\hline BCB-22 & $\begin{array}{c}\text { Solitary + } \\
\text { Cluster }\end{array}$ & 3 to 4 & $5: 0: 0: 4$ & Light violet & Green & $\begin{array}{l}\text { Highly } \\
\text { thorny }\end{array}$ & $\begin{array}{c}\text { Fully } \\
\text { opened }\end{array}$ \\
\hline BCB-27 & $\begin{array}{c}\text { Solitary + } \\
\text { Cluster }\end{array}$ & 2 to 3 & $2: 0: 5: 0$ & Light violet & Green & $\begin{array}{l}\text { Medium } \\
\text { thorny }\end{array}$ & $\begin{array}{c}\text { Half } \\
\text { opened }\end{array}$ \\
\hline
\end{tabular}


Fig.1 Anthesis-Full bloom stage-Anther dehiscence

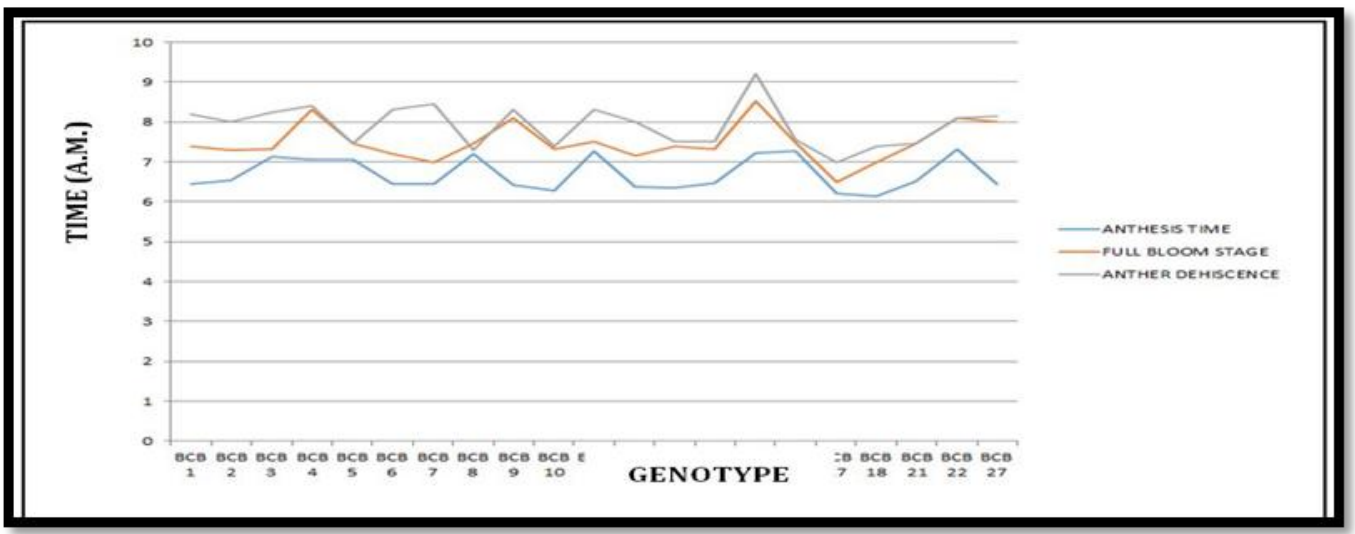

Fig.2 Stigma receptivity

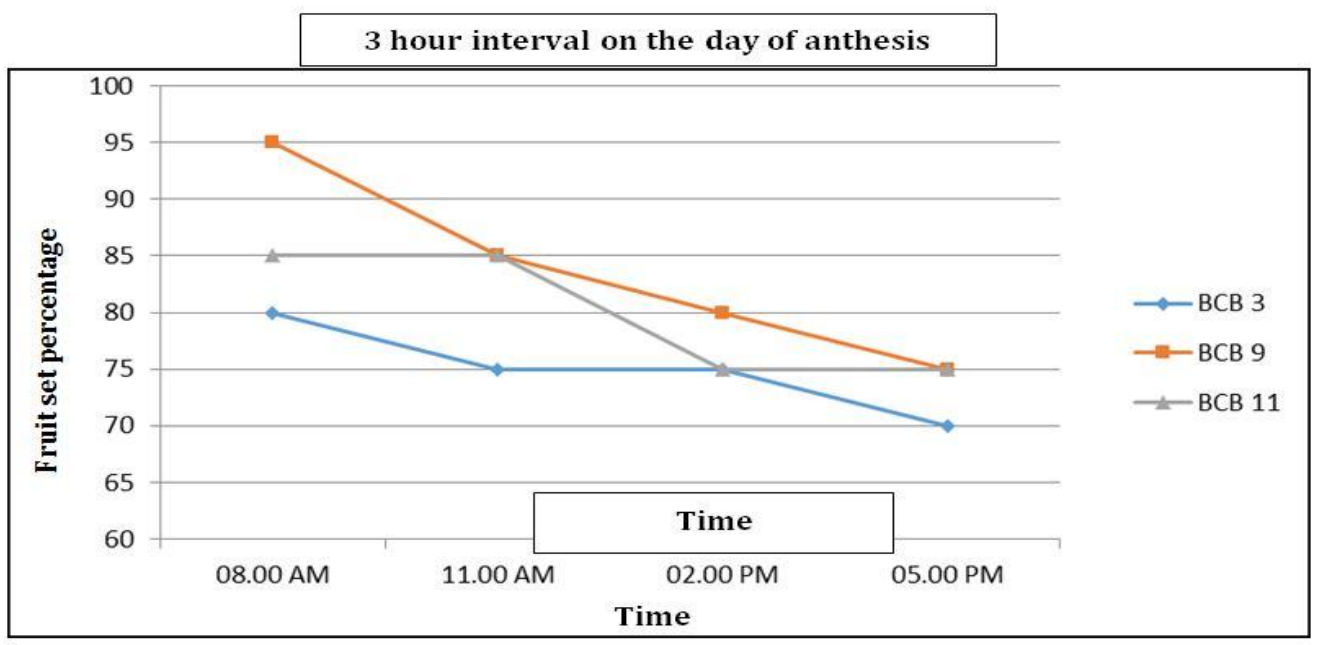

Fig.3 Stigma receptivity

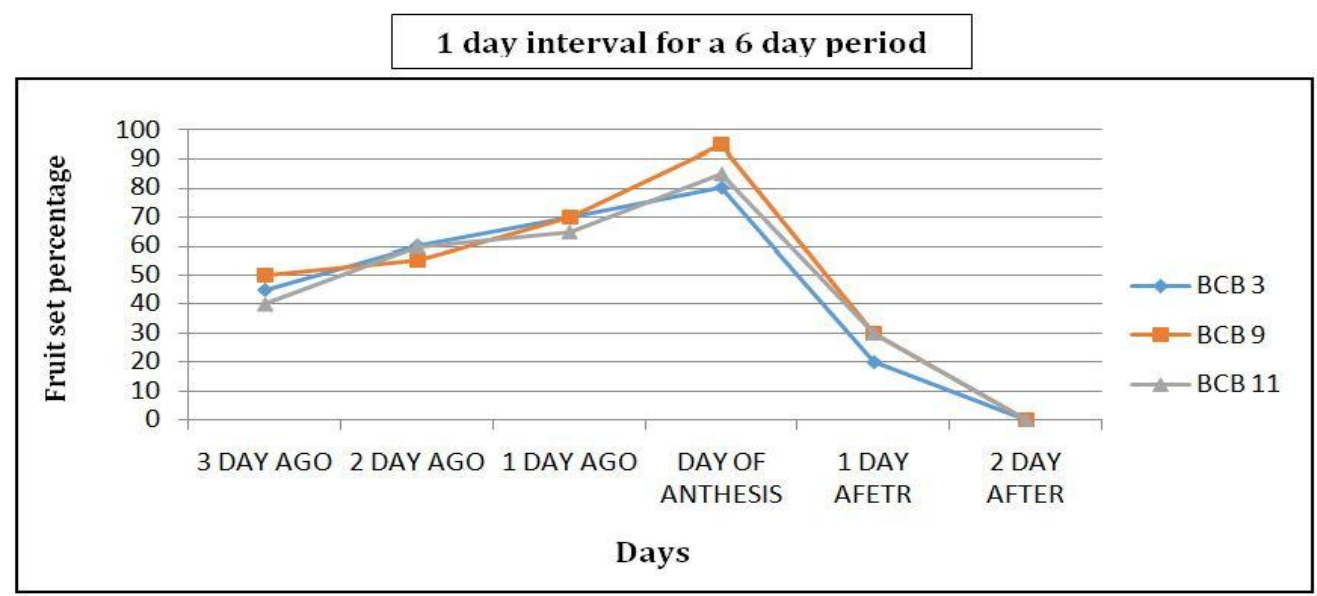

\section{Other floral characters}

In the present investigation, majority of the genotypes possessed mixed type (solitary and cyme) flowering pattern except BCB-2, 4, 9, 13 and 15, which were of solitary flowering type. In the solitary flowering genotype functionally fertile flowers set fruits where as 
in genotypes with mixed type flowering pattern, number of flowers/cyme did vary from 2-6 (Table-5); in almost $87 \%$ of the genotypes the flower structure of fully open orientation was recorded with light-pale violet to bluish violet corolla colour.

A close perusal of the data in the Table-5 authenticates that in the mixed cymes the range of non-productive flowers (both PS+SS) spanned from 0-6 and that in the cluster flowering genotypes, only few additional flowers were fertile to set fruits.

\section{Anthesis-full bloom-anther dehiscence}

It has been noticed that the anthesis starts earliest in BCB-18 (6:14 a.m.) and latest by 7:51 a.m. in BCB-11. Full bloom stage generally occurred from 6:50 a.m. (BCB-17) to 8:52 a.m. (BCB-15) and anther dehiscence from 7:00 a.m. (BCB-17) to 9:20 a.m. (BCB$15)$.

From the graphical presentation (Fig.1), it can be easily understood that in case of some genotypes, the anther dehiscence line coincides or crossed over the full bloom line indicator that means for those genotypes anther dehiscence occurs at the full bloom stage or just before the full bloom stage. In case of BCB-4, ВCB-5, ВCB-8, ВCB-9, BCB-13, BCB-18, BCB-21 and BCB-22, the time of anther dehiscence and full bloom stage is almost same. Same trend of result have been obtained by Oyelana and Ogunwenmo (2012), Deshpandey et al., (1978), Basavaraja (1986).

\section{Stigma receptivity}

On the day of anthesis, stigma receptivity was highest at around 8:00 a.m., and just after the anthesis it declined slowly afterwards (Fig2.1). Oyelana and Ogunwenmo (2012), Hazra et al., 2003) also stated the same earlier. From Fig.-2.2, it can be noted that stigma became receptive from 3 days before anthesis and remain so 1 day after anthesis, receptivity being maximum on the day of anthesis. Three days before and 1 day after anthesis, there was no fruit set instead of hand pollinating the flowers with viable pollens and this result is supported by Deshpandey (1978) and Basavaraja (1986) but Pal and singh (1943) and Popova (1962) reported long extended stigma receptivity up to 9 days after anthesis.

\section{Parthenocarpy}

Parthenocarpic fruit set in all the genotypes have been studied and it was noted that propensity to parthenocarpic fruit set in brinjal was low. Parthenocarpic fruit set was noted in BCB-6, BCB-11, BCB-14, BCB-15 and BCB-16. There are many results of natural parthenocarpy like, Shibing et al., (2003) and Bailey and Munson (1891).

All these twenty one genotypes of brinjal differed significantly for most of floral characters under study. The floral bud initiation, 50\% flowering, total flowering period and productive: non-productive flower ratio varies from 40.83-58.17 DAT, 50.5068.33 DAT, 133.10-86.67 days and 0.5611.52 respectively. Anther length, style length, ovary diameter and ovary weight of brinjal varies from $4.00-13.73 \mathrm{~mm}, 0.74-$ $13.53 \mathrm{~mm}, 1.30-6.93 \mathrm{~mm}$ and $0.0007-0.2 \mathrm{gm}$. Anthesis, full bloom and anther dehiscense generally occurs during 6:14-7.51 a.m., 6:508:52 a.m. and 7:00-9:20 a.m. Stigma receptivity is highest on the day of flower opening and in morning anthesis time. So, any kind of hybridization programme should be operated morning on the day of anthesis. Occurrence of parthenocarpic fruit development is less. Majority of the genotypes possessed mixed type (solitary and cyme) flowering pattern with fully opened violet flower and smooth calyx. Number of flowers/cyme did vary from 2-6. Calyx colour varies from green to violet. The highest ratio 
of (LS+MS): (PS+SS) flowers have been recorded in the genotype BCB-10 (11.52) followed by BCB-8(10.33) and these two genotypes may be used in future as maximum fruits/yield can be achieved.

\section{References}

Bailey, L.H., and Munson, W.H. 1891. Experiences with eggplants. Bull Cornell Agric. Exp. Sta. 26: 21-26.

Basavaraja, N., 1986. Studies on hybrid seed production in brinjal (Solanum melongena L.). Mysore J. Agri. Sci. 20(3): 249.

Chen, N. C., 2001. "Eggplant seed production." AVRDC International Cooperators' Guide. Asian Vegetable Research and Development Center, Shanhua, Taiwan: 1-14.

Deshpande, A.A., Bankapur, V.M. and Nalawadi, U.G. 1978. Some aspects of blossom biology in brinjal varieties (Solanum melongena L.). Current Res. University of Agricultural Sciences, Bangalore. 7(10): 174-175.

Dhaka, K.S., and Soni, K.A. 2012. Genetic variability in brinjal (Solanum melongena L.). The Asian J. Hort. 7: 537-540.

Gavade, T.R., and Ghadage, A.B. 2015. Genetic Variability, Heritability and Genetic Advance in Segregating Generation of Brinjal (Solanum melongena L.). Bioinfolet. 12(1C): 325-328.

Hazra, P., Mondal, J. and Mukhopadhyay, T. P. 2003. Pollination behavior and natural hybridization in Solanum melongena L. and utilization of the functional male sterile line in hybrid seed production. Capsicum and Eggplant Newsletter. 22: 143-146.

Nothmannet, J., Rylski, I. and Spigelman, M. 1983. Floral morphology and position, cluster size and season fruit set in different eggplant cultivars. $J$. Hort. Sci. 58: 403-409.
Oyelana, O.A., and Ogunwenmo, K.O. 2012. Floral biology and the effects of plantpollinator interaction on pollination intensity, fruit and seed set in Solanum. African $J$. Biotech. 11(84): 14967-14981.

Pal, B.P., and Singh, H.B. 1943. Floral characters and fruit formation in egg plant. Indian J.Genet. 31(1): 45-58.

Pandit, M.K., Thapa, H., Akhtar, S. and Hazra, P. 2010. Evaluation of brinjal genotypes for growth and reproductive characters with seasonal variation. J. Crop and Weed. 6: 3134.

Passam, H. C., and Bolmatis, A. 1997. The influence of style length on the fruit set, fruit size and seed content of aubergines cultivated under high ambient temperature. Trop. Set. 37: 221-227.

Popova, D., 1958. The influence of some factors of the hybrid seeds and F1 generation in egg plant. Agrobiologia. 2: 213-218.

Quagliotti, L., 1979. Floral biology of Capsicum and Solanum melongena. In: Solanaceae The biology and taxonomy of Solanaceae. (Ed.), J.G.Hawkes, R.N. Lester and A.D. Skelding. Pub: Academic press London, pp. 399-419.

Shibing, T., Fuzhong, L., Yongqing, T., Luo Zhangyong, L., Yikang, C., Liu Junsha, L. and Yunju, H. 2003. Genetic analysis of Parthenocarpy in Eggplant. Acta Horticulture.

Vandana, Y., Nandan, M. and Smita, B. 2014. Variability and Heritability Estimates in the Germplasm Collection of Egg Plant (Solanum melongena L.). Trends in Biosciences. 7(21): 3482-3484.

Vidhya, C., and Kumar, N. 2015. Research Article Genetic variability studies in Brinjal (Solanum melongena) for fruit yield and quality. Electronic Journal of Plant Breeding. 6(3): 668-671.

\section{How to cite this article:}

Arindam Das, Manas Kumar Pandit, Sanjay Bairagi, Shubhrajyoti Saha and Kola Muthaiah. 2017. A Study on Floral Morphology of Brinjal Genotypes in Gangetic-Alluvial Zone of West Bengal. Int.J.Curr.Microbiol.App.Sci. 6(10): 3323-3331. doi: https://doi.org/10.20546/ijcmas.2017.610.389 